\title{
Preliminary Study of Electrochemical Behavior of Ketjen Black Modified Glassy Carbon Electrode (GCE) in Dopamine Solution
}

\author{
Firman Ardyansyah*, Fredy Kurniawan ${ }^{\dagger}$ \\ Faculty of Science and Data Analytics, Institut Teknologi Sepuluh Nopember (ITS), Kampus ITS Sukolilo, \\ 60111 Surabaya, Indonesia
}

(Received 21 March 2021; revised manuscript received 15 June 2021; published online 25 June 2021)

\begin{abstract}
Modification of a glassy carbon electrode (GCE) using Ketjen black has been done. Ketjen black (KB) was attached to the GCE surface employing the drop-casting method with the support of sodium cholate as a surfactant. The measurement was performed using cyclic voltammetry. The preliminary study of the electrochemical behavior of KB-modified GCE was observed using $1 \mathrm{mM}$ dopamine in acetate buffer $p H 4$ as a supporting electrolyte. The result shows that the anodic peak current of a modified GCE is higher than that of a GCE without modification. It indicates that KB gives a synergy effect for GCE to increase the anodic peak current of dopamine measurement. In selectivity studies, modification of a GCE using KB can improve the selectivity of the sensor. An unmodified GCE is selective for dopamine, uric acid, ascorbic acid, and glucose. After modification of the surface, a GCE is only selective for dopamine. In electrochemical behavior study, five repetitions of measurement resulted in a decrease in the anodic peak current. It indicates that the oxidation product of dopamine molecules is attached strongly to the surface of the KB modified GCE surface during voltametric measurement causing a decrease in the anodic peak current.
\end{abstract}

Keywords: Modified electrode, Ketjen black, Electroanalysis, Dopamine.

\section{INTRODUCTION}

In the human body, dopamine is found in the arcuate nucleus in the hypothalamus of the brain [1]. The main function of dopamine is as an neurotransmitter [2]. In humans, dopamine is found in the range from 0.01 to $1 \mu \mathrm{mol} / \mathrm{l}$ [3]. A low level of dopamine in the human body can cause some diseases, i.e., Alzheimer, Parkinson, and Schizophrenia [1].

Various research on the method of dopamine detection has been developed. One of method is electrochemical method $[2,4]$. Working electrodes that have been reported as dopamine sensors are silver, platinum, gold [2], and carbon-based electrodes [5]. One type of carbonbased electrode that is interesting to develop is the glassy carbon electrode (GCE) [6]. This type of electrode has the advantages of having good mechanical and electrical properties, a wide potential window, and is inert to chemicals [7]. To increase the selectivity and strengthen the conductivity of the sensor to the analyte to produce a specific signal for a certain type of compound, surface of sensor can be modified with other materials [8].

Ketjen black (KB) is a promising material for electrode modification [9] because of its high conductivity and specific surface area and very porous [10]. This makes the surface area of this material very large and can absorb a lot of analytes when used as a material for modification of electrochemical sensors [11].

However, dopamine analysis using KB-modified GCE faces several problems. First, interference reaction due to the presence of other compounds such as ascorbic acid, uric acid, urea and glucose in biological fluids that also oxidized can disrupt the detection of dopamine [12]. Second, the contamination of the sensor surface due to the absorption of oxidation products from dopamine able to decrease reproducibility of the sensor [13].

In this research, the electrochemical responses of an unmodified GCE and KB-modified GCE on dopamine solution and interference test using glucose, ascorbic acid, uric acid, and urea has been studied.

\section{TOOLS AND MATERIALS}

\subsection{Tools}

The tools used in this study were a set of simple glassware, micro pipettes, digital scales, sonicators, and pH meters. Measurement of current response using a Metrohm AUTOLAB Type PGSTAT 128N potentiostat and NOVA 1.11 software.

\subsection{Materials}

Dopamine $\left[\mathrm{C}_{8} \mathrm{H}_{11} \mathrm{NO}_{2}, 98 \%\right.$ ] was purchased from sigma Aldrich and used without any purification. Uric acid $\left[\mathrm{C}_{5} \mathrm{H}_{4} \mathrm{~N}_{4} \mathrm{O}_{3}\right]$ with $99 \%$ purification purchased from sigma Aldrich. Ascorbic acid $\left[\mathrm{C}_{6} \mathrm{H}_{8} \mathrm{O}_{6}\right]$, glucose $\left[\mathrm{C}_{6} \mathrm{H}_{12} \mathrm{O}_{6}\right]$ and urea $\left[\mathrm{CO}\left(\mathrm{NH}_{2}\right)_{2}\right]$ were purchased from Merck. Ketjen Black EC 600 JD from LION Specialty Japan, Sodium Cholate (HiMedia Laboratories), Acetate Buffer $p H 4$ and demineralized water for cleaning and chemical preparation.

\section{RESULTS AND DISCUSSION}

\subsection{Electrode Fabrication}

In this research, GCE was modified using $\mathrm{KB}$ by drop-casting. Briefly, $\mathrm{KB}$ as a modification material was suspended in water. Sodium cholate as a surfac-

\footnotetext{
* firman.ardyansyah25@gmail.com

† fredy@chem.its.ac.id

The results were presented at the International Conference on Innovative Research in Renewable Energy Technologies (IRRET-2021)
} 
tant was added to support adhesion of KB on the surface of GCE and mixed it slowly to homogenize the suspension. Then this homogeny suspension was dropped on the surface of GCE using micropipette and wait until the GCE surface dried. Then modified layer will be formed. This KB-modified GCE was stored in the vacuum desiccator to avoid any contamination of the electrode surface.

\subsection{GCE Responses Test to the Dopamine Solution}

Fig. 1 shows the voltammogram result of dopamine measurement using an unmodified GCE and KBmodified GCE. The voltammogram shows that the anodic peak current of the unmodified GCE is lower than that of a modified GCE. Increasing of anodic peak current of KB-modified GCE indicate that $\mathrm{KB}$ gives synergic effect to improve the GCE performance.

Modification of GCE using KB not only increases the anodic current peak, but also improves the selectivity of the sensor. Fig. 2 shows that unmodified electrode gives responses to dopamine, uric acid, ascorbic acid, and glucose. Comparing with the KB-modified electrode in Fig. 3, sensor only gives response with dopamine.

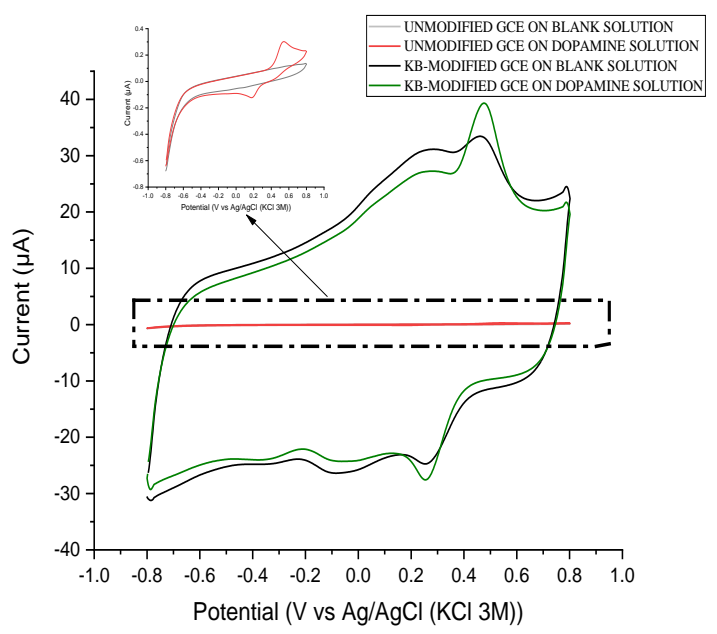

Fig. 1 - Voltammogram of $1 \mathrm{mM}$ dopamine solution in acetate buffer $p H 4$ using the unmodified GCE and KB-modified GCE

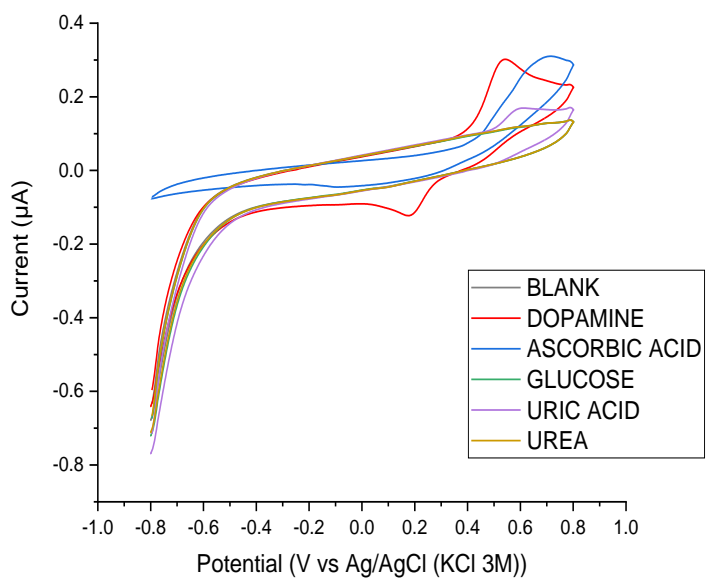

Fig. 2 - Voltammogram of $1 \mathrm{mM}$ dopamine, ascorbic acid, glucose, uric acid, and urea solution in acetate buffer $p H 4$ using an unmodified GCE

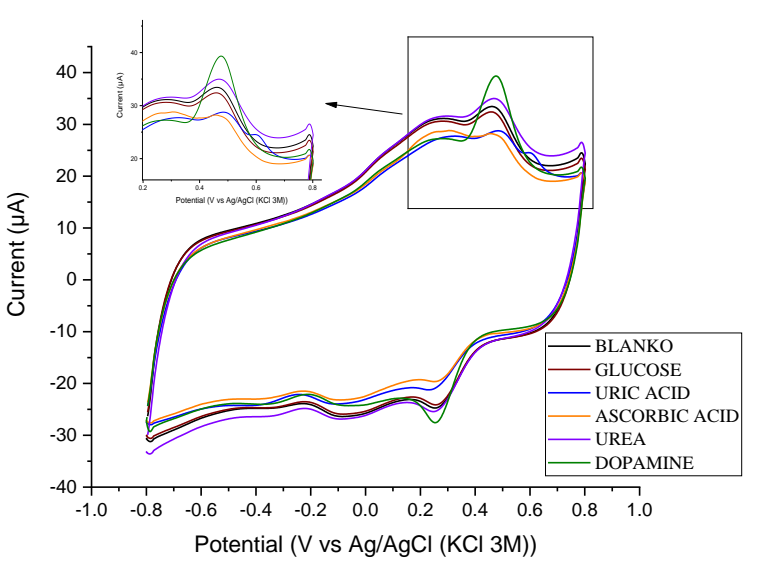

Fig. 3-Voltammogram of $1 \mathrm{mM}$ dopamine, ascorbic acid, glucose, uric acid, and urea solution in acetate buffer $p H 4$ using a KB-modified GCE

\subsection{Electrochemical Behavior}

After pre-study of KB-modified GCE has been conducted, the electrochemical behavior of KB-modified GCE was studied using 5 continuous measurements of dopamine solution. The voltammograms show that the anodic peak current decreases during measurement from the first cycle to the fifth cycle (Fig. 4).

From the results, it indicated that modified electrode surface poisoned by dopamine molecules after voltametric measurement. These phenomena cause a decrease in the anodic peak current and a decrease in the electrode performance.

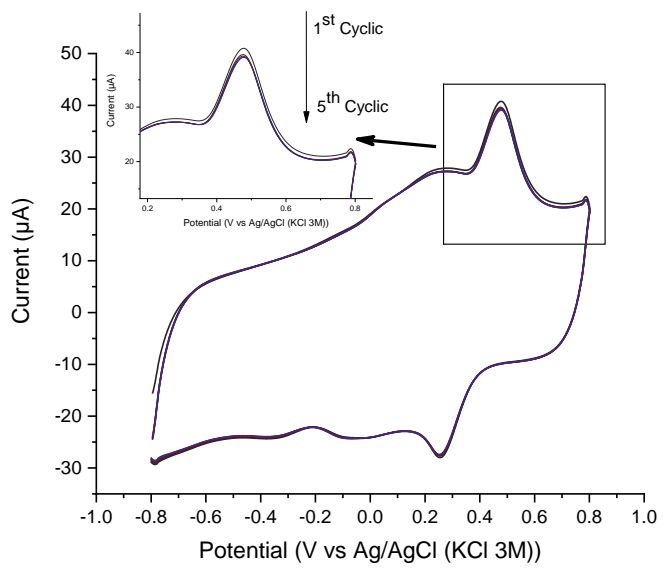

Fig. 4 - Five cycles of voltammogram of $0.1 \mathrm{mM}$ dopamine in acetate buffer $p H 4$

\section{CONCLUSIONS}

The performance of a KB-modified GCE toward dopamine solution was investigated. Modification of GCE using $\mathrm{KB}$ is able to increase the anodic peak current and improve the selectivity of the GCE for dopamine detection. Dopamine molecules can poison the KBmodified GCE surface, as indicated by a decrease in the anodic peak current of voltammogram during five continuous measurements using the same dopamine solution sample. 


\section{ACKNOWLEDGEMENTS}

We acknowledge Indonesia Endowment Fund for
Education for the financial support and Japan-Asia Youth Exchange Program in Science for the joint research program in Saga University, Japan.

\title{
REFERENCES
}

1. F. Kurniawan, V. Tsakova, V.M. Mirsky, J. Nanosci. Nanotechnol. 9, 2407 (2009).

2. F. Kurniawan, N.S.A. Kiswiyah, K.A. Madurani, M. Tominaga, ECS J. Solid State Sci. Technol. 6, M3109 (2017).

3. A. Zahri, A. Sudrajat, M.J. Zairin, Profil Hormon FSH, LH Dan Estradiol Serta Kadar Glukosa Darah Sidat, Anguilla Bicolor (Mc Clelland, 1844) Yang Dirangsang Hormon HCG, MT, E2 Dan Anti Dopamin, Journal Iktiologi Indonesia 18 57 (2018).

4. Q. Gong, H. Han, Y. Wang, C. Yao, H. Yang, J. Qiao, Carbon 167, 931 (2020).

5. Z. Wang, H. Guo, R. Gui, H. Jin, J. Xia, F. Zhang, Sensor. Actuat. B: Chem. 255, 2069 (2018).

6. M. Afrasiabi, S. Kianipour, A. Babaei, A.A. Nasimi, M. Shabanian, J. Saudi Chem. Soc. 20, S480 (2016).

7. A. Rofiansyah, M. Tominaga, F. Kurniawan, IOP Conf. Ser.: Mater. Sci. Eng. 494, 012049 (2019).

8. Z. Zulkarnain, S. Suprapto, T. Ersam, F. Kurniawan, Indonesian Journal of Electrical Engineering and Computer Science 3, 3 (2016).

9. Y. Sun, X. Jiang, H. Jin, R. Gui, Analytica Chimica Acta 1083, 101 (2019)

10. K. Madurani, S. Suprapto, N. Machrita, S. Bahar, W. Illiya, F. Kurniawan, ECS J. Solid State Sci. Technol. 9, 093013 (2020).

11. L. Shen, H. Ding, Q. Cao, W. Jia, W. Wang, Q. Guo, Carbon 11, 4284 (2012).

12. S.R. Ali, R.R. Parajuli, Y. Ma, Y. Balogun, H. He, J. Phys. Chem. B 111, 12275 (2007).

13. F. Kurniawan, New Analytical Applications of Gold Nanoparticles, Ph.D. Thesis (2009).

\section{Попередне дослідження електрохімічної поведінки скловуглецевого електрода (GCE), модифікованого Ketjen black, у розчині дофаміну}

\author{
Firman Ardyansyah, Fredy Kurniawan \\ Faculty of Science and Data Analytics, Institut Teknologi Sepuluh Nopember (ITS), Kampus ITS Sukolilo, \\ 60111 Surabaya, Indonesia
}

\begin{abstract}
Здійснено модифікацію скловуглецевого електрода (GCE) з використанням Ketjen black (KB). KB був прикріплений до поверхні GCE із застосуванням методу краплинного лиття за підтримки холата натрію як поверхнево-активної речовини. Вимірювання проводили за допомогою циклічної вольтамперометрії. Попередне дослідження електрохімічної поведінки GCE, модифікованого КВ, проводили з використанням $1 \mathrm{mM} \mathrm{дофаміну} \mathrm{в} \mathrm{ацетатному} \mathrm{буфері} \mathrm{з} p H=4$ як підтримуючому електроліті. Результат показуе, що анодний піковий струм модифікованого GCE вищий, ніж струм GCE без модифікації. Це вказуе на те, що $\mathrm{KB}$ дає синергічний ефект для GCE для збільшення анодного пікового струму при вимірюванні з дофаміном. У дослідженнях селективності модифікація GCE за допомогою КВ може поліпшити селективність датчика. Немодифікований GCE є селективним щодо дофаміну, сечової кислоти, аскорбінової кислоти та глюкози. Після модифікації поверхні GCE є селективним лише для дофаміну. При дослідженні електрохімічної поведінки п'ять повторень вимірювань призвели до зменшення анодного пікового струму. Це вказуе на те, що продукт окислення молекул дофаміну міцно прикріплюеться до поверхні GCE, модифікованого KB, під час вольтаметричного вимірювання, що спричинюе зменшення анодного пікового струму.
\end{abstract}

Ключові слова: Модифікований електрод, Ketjen black, Електроаналіз, Дофамін. 